University of Nebraska - Lincoln

DigitalCommons@University of Nebraska - Lincoln

Faculty Publications: Department of Teaching, Department of Teaching, Learning and Teacher Learning and Teacher Education

Education

2015

Skirting around Critical Feminist Rationales for Teaching Women in Social Studies

Mardi Schmeichel

Follow this and additional works at: https://digitalcommons.unl.edu/teachlearnfacpub

Part of the Curriculum and Instruction Commons, and the Teacher Education and Professional

Development Commons

This Article is brought to you for free and open access by the Department of Teaching, Learning and Teacher Education at DigitalCommons@University of Nebraska - Lincoln. It has been accepted for inclusion in Faculty Publications: Department of Teaching, Learning and Teacher Education by an authorized administrator of DigitalCommons@University of Nebraska - Lincoln. 

.1002648

Copyright (C) 2015 College and University Faculty Assembly of National Council for the Social Studies. Published by Routledge/Taylor and Francis. Used by permission.

Published online February 19, 2015.

\title{
Skirting around Critical Feminist Rationales for Teaching Women in Social Studies
}

\author{
Mardi Schmeichel \\ Department of Educational Theory and Practice, College of Education, University of Georgia, Athens, \\ Georgia, USA \\ Corresponding author - Mardi Schmeichel, Department of Educational Theory and Practice, College of Education, \\ University of Georgia, 630 Aderhold Hall, Athens, GA 30602, email mardi@uga.edu
}

\begin{abstract}
Feminist practices can provide firm theoretical grounding for the kind of social studies that scholars promote, especially in relation to efforts to include women in the curriculum. However, in P-12 social studies education, neither women nor feminism receive much attention. The study described in this article was a discourse analysis of 16 recently published lesson plans that did include women. Through this examination of the rationales and language used to promote teaching about women, the author sheds light on some discursive obstacles inhibiting attention to gender issues in critical feminist ways and argues that by shifting norms in the field, we can realize feminism's potential to contribute to both social studies and ongoing discussions about women and gender inequity in society.
\end{abstract}

Keywords: critical theory, discourse analysis, feminism, neoliberalism, women

The gender hierarchy in the United States has reemerged as a topic of national discussion in the past few years, reflecting a renewed interest in a dialog about women's position in society. Arguments about the obstacles that women face (or not) on the basis of their gender have erupted in spaces ranging from debates regarding women's access to contraception in the Affordable Care Act to the systematic attempt to dismantle abortion rights and access to family planning, particularly in communities serving poor and rural women. When considered alongside unlegislated spaces in which attention to gender inequity has 
been drawn, such as the absence of women from boards of directors of technology companies (Bajaj, 2013) or the hateful, violent rhetoric about women circulating online, perhaps best encapsulated in the attacks against media critic Anita Sarkeesian (Greenhouse, 2013; Sarkeesian, 2012), there is little question that issues of gender inequity have once again risen to the top of our national consciousness.

The same theme runs through many of these conversations. If you think we are living in a post-sexist world, you are wrong. Gender inequality is not something we have moved beyond. Indeed, these recent conversations about sexism and gender inequity in our country are not pointing to a new phenomenon. Although the contexts have changed, very similar conversations emerged in the public domain during the Women's Rights Movement of the 1960s and 1970s. What is different now is that these conversations, and the negative attitudes regarding women that have surfaced because of them, are rearing their heads at a time in which the feminist stance that could empower women and girls to push back against this rhetoric has been positioned as unpalatable and irrelevant.

Since the 1960s, feminists have made great strides in combatting sexism and uncloaking patriarchal norms. Their political work and theorization of gender inequity has been instrumental in creating substantially different life opportunities for women and men when compared to the options available 50 years ago. While there has been substantial dissention within feminism over the last three decades with regard to its classist, racist, colonial, and heteronormative origins and orientations (e.g., Henry, 2004; Mohanty, Russo, \& Torres, 1991; Morago \& Anzaldúa, 2002; Tea, 2003; Walker, 1992), the most substantial obstacles to feminist work have come from efforts outside the movement to position feminism as unpleasant and unnecessary. In this period of the reemergence of gender as a significant issue within national discussion, however, feminism has the potential to be a particularly productive force. As part of a critical theoretical tradition that seeks to analyze power structures and their impact on shaping knowledge of the world (Segall, 2013), feminism(s) ${ }^{1}$ provide tools with which to deconstruct and understand inequality, now and in the past, as well as strategies for creating spaces of resistance within oppressive structures. Importantly, feminism encourages consideration of how these systems and the narratives they elicit shape our realities, providing an interrogative stance from which to question the continued marginalization of women in the United States and elsewhere.

\section{Feminism and Social Studies}

Feminism has been and continues to be highly relevant to social studies in particular. Across work spanning several decades, feminist pedagogues have argued that feminism has much to offer social studies (e.g., Alpern, 1978; Bernard-Powers, 1996; Crocco, 2004; Maher, 1987; Stone, 1996). Many of these authors have pointed out that feminist theories promote the same practices and strategies that receive considerable attention in social studies research. For example, feminism encourages responsiveness to positionality, situatedness, identity, location, and history - the same kinds of understandings upon which the implementation of multiple perspectives in history education relies. Furthermore, feminism emphasizes the understanding that knowledge is socially constructed and histori-

cally and culturally located, which are important tenets in social educators' work to create 
spaces for students to interact with standards and curriculum in critical ways. As a theoretical stance that is "aimed at interrupting relations of dominance" (Lather, 1991, p. 122), feminist practices promote inquiry and questioning, provide access to alternative discourses to "read" the canon, and position the curriculum itself to be a site of critique. As such, feminisms have much to offer in terms of providing firm theoretical grounding for the kinds of social studies practices that scholars promote. Feminism would seem to be an ideal partner to such a field as social studies and its interdisciplinary concern for the examination of culture, society, and power now and in the past. Its relevance is evident, for example, through the regular use of feminist theory within each of the disciplines from which social studies education draws it content.

However, in $\mathrm{P}-12$ and social studies teacher education practice, the silence on feminism is deafening. The women's and feminist movement and the explosion of scholarship in women's and gender studies in the rest of academia have had very little impact on the traditional social studies curriculum in the United States (see Hahn, Bernard-Powers, Crocco, \& Woyshner, [2007] and Hahn et al. [1985] for an overview of the scant attention to gender in social studies). This is of significant concern for those of us who see social studies classrooms as spaces with the potential to shape students' understandings of the world. If, as DeLeon (2010, p. vii) has argued, "traditional status quo social studies education reproduces problematic assumptions about the world around us" (p. vii), then a traditional status quo social studies in which women are marginalized or absent contributes to problematic assumptions about women.

Although there has been some attention paid to this absence, most of the empirical research about women and the social studies curriculum has focused on documenting women's absence from textbooks and standards. This documentation has been important, but with the exception of such studies as Schmidt's (2012) close examination of the contexts in which women appear in one set of state standards, this body of work has not explored how women are present in the curricula and, specifically, whether or not the limited examples in which women do appear are opening up gender inequity as a topic to be discussed in critical ways. Further, although early work promoting attention to women in the field was motivated by and situated within feminist theoretical and political frameworks (e.g., Hahn, 1975; Maher, 1987; Tetreault, 1987; Trecker, 1971), the use of feminism as a theoretical construct to support social studies research and pedagogy has declined significantly (Crocco, 2004; Schmeichel, 2011). While there is literature documenting the absence of women from social studies, the presence or absence of feminism as a theoretical construct or rationale for including attention to women in social studies education is limited.

In the project described in this article, I paid close attention to one type of social studies curricula - published lesson plans - to consider what arguments were used to justify teaching about women and to see if feminism was called upon in lessons that included women. By looking at the rationales the authors used to promote the implementation of these lesson plans, as well as looking for the presence of feminist discourses in the texts, I sought to contribute to research on women and social studies through a study of practitioneroriented texts that considered what is shaping authors' rationales for including women in social studies lessons. Through an analysis of what gets said about including women in social studies, as well as how it gets said, I shed light on some possible discursive obstacles 
inhibiting attention to gender issues in critical feminist ways and argue that a shift in norms in the field can contribute to the realization of feminism's potential to contribute to both social studies and ongoing discussions about women and gender in society.

\section{Discourse and Normalizing Texts}

My interest in examining texts produced for teachers reflects a poststructural theoretical orientation toward thinking about language as a "medium for action" (Hicks \& Taylor, 2008 , p. 53) and the understanding that the manner in which these topics are presented has a constitutive force. In other words, texts that encourage the inclusion of women in the curriculum not only describe ways to teach a lesson but also promote a set of possible orientations toward the task of including women in the curriculum in general, reflecting the power of language to "create what it seems simply to describe" (MacLure, 2003, p. 4). This view of language builds on discourse theories forwarded by Foucault (1977), who described discourse as the "delimitation of a field of objects, the definition of a legitimate perspective for the agent of knowledge, and the fixing of norms for the elaboration of concepts or theories" (p. 199). Through the repeated attention to particular topics and the repeated descriptions of how to teach them, published lesson plans contribute to shaping the community's understanding of what issues are worth addressing in social studies education classes and how they should be addressed. As such, repeated encounters with the texts produced by the field contribute to the normalization of what counts as social studies (Segall, 2004). In this case, the texts produced in the discipline contribute to influencing and shaping what educators and scholars think about feminist theories or including women in the curriculum, making it seem "normal" to think about these topics in some ways but not others. Discourse analyses are concerned, in particular, with unraveling these takenfor-granted constructions by disrupting "the naturalness or inevitability of identities, values, and concepts, thus showing the workings of power and material interests in the most seeming innocent of texts" (MacLure, 2003, p. 9).

The discourses that justify attending to women in social studies are informed by the discourses about women that exist in our culture. But social studies education has its own history in terms of addressing and ignoring gender. Integrating women into social studies curriculum is not a neutral act. The examination of texts that do seek to address this absence can provide some insight into the discourses available to authors who seek to assert that facilitating a lesson about women is worthwhile within a discipline in which women as a topic have been marginalized. Keeping in mind the history of the field's attention to women and building on poststructural conceptions of the force of language, I conducted a discourse analysis that was guided by the following questions:

Why this version or this utterance? What does it do? What does it accomplish here and now? And what does it tell us about the wider discursive economy of the politics of representation that influences what is available to be said and what can be heard? (Wetherell, 2001, p. 17) 
These questions position the lesson plans not just as instructions for pedagogical events but as acts of persuasion used to do a particular kind of work. The texts may, on the surface, appear as straight-forward descriptions of lessons, but instead of accepting these lessons as unproblematic, my analysis focused on how the lessons drew from and reinscribed particular ways of thinking about why women should be included in curriculum. With this focus, a discourse analysis exceeds a description of what a text is about and, instead, interrogates what a text does.

Because, as Fairclough (2003) asserted, "a published text can figure in many different processes of meaning-making and contribute to diverse meanings, because it is open to diverse interpretations" (p. 11), a textual analysis cannot directly address the variety of ways these lessons may have been implemented in individual classrooms. I am not making any claims about how they may have been enacted, disrupted, altered, or ignored by their readers. However, as poststructural theories contend, all discursive practices have effects (MacLure, 2003). Therefore, the texts themselves are as worthy of consideration as the future research that might examine how these lesson plans are enacted in classrooms.

\section{Data Collection}

Teachers receive potential lesson plans from many sources: curriculum publishers, the internet, other teachers, etc. In this study, however, I was interested specifically in lesson plans available in sources that, through affiliation with the National Council for the Social Studies (NCSS) and/or because they include publications written by social studies academics, may represent the "official" discourses of social studies to teachers. I identified six publications that were searchable in the Education Resources Information Center (ERIC) and geared toward social studies practitioners-Social Education, Social Studies \& the Young Learner, Middle Level Learner, Journal of Social Studies Research, The Social Studies, and International Journal of Social Education. ${ }^{2}$ These publications focus solely on social studies education and include articles that social studies researchers and teacher educators gear toward practicing P-12 teachers. The first step in collecting the data was to build an ERIC search that would capture journal articles that included women and described lesson plans. To do this, I used ERIC descriptors, which are terms assigned by the ERIC Lexicography staff that label the major topics of an ERIC document. My search included 29 descriptors related to gender and 26 descriptors related to instruction. ${ }^{3}$

Table 1 illustrates the results of the search conducted within the six social studies journals used for this project. Among the 1,085 instruction-related articles in the journals, only 33 , or $3 \%$, included descriptors that were related to gender. 
Table 1. Articles Published 2000-2011

\begin{tabular}{|c|c|c|c|c|c|}
\hline Journal & All articles & $\begin{array}{c}\text { Number of } \\
\text { articles with } \\
\text { instruction } \\
\text { descriptors }\end{array}$ & $\begin{array}{l}\text { Number of } \\
\text { articles with } \\
\text { gender } \\
\text { descriptors }\end{array}$ & $\begin{array}{l}\text { Number of } \\
\text { articles with } \\
\text { at least one } \\
\text { instruction } \\
\text { and gender } \\
\text { descriptor }\end{array}$ & $\begin{array}{l}\text { Number of } \\
\text { lesson plan } \\
\text { articles } \\
\text { included in } \\
\text { this study }\end{array}$ \\
\hline Social Education & 601 & 409 & $40^{\mathrm{a}}$ & 15 & 8 \\
\hline $\begin{array}{l}\text { Journal of Social } \\
\text { Studies Research }\end{array}$ & 75 & 48 & 1 & 0 & 0 \\
\hline $\begin{array}{l}\text { Social Studies and the } \\
\text { Young Learner }\end{array}$ & 230 & 155 & 6 & 2 & 1 \\
\hline The Social Studies & 469 & 299 & 16 & 9 & 3 \\
\hline Middle Level Learner & 155 & 131 & $7^{\mathrm{b}}$ & 6 & 4 \\
\hline $\begin{array}{l}\text { International Journal of } \\
\text { Social Education }\end{array}$ & 106 & 43 & 3 & 1 & 0 \\
\hline Total & 1,636 & 1,085 & 73 & 33 & 16 \\
\hline
\end{tabular}

aTwelve in one special issue.

bFour in one special issue.

I read each of the 33 articles containing at least one instruction and gender descriptor. I evaluated each article on the basis of two criteria. First, because I sought to include articles that could be characterized as "lesson plans," I considered the attention devoted to describing classroom activities for elementary, middle, or high school students and teachers. Second, I evaluated the content for the degree of focus placed on women's history or women's issues. More than half of the 33 articles from the search failed to meet one or both of these criteria. For example, there were articles in the search that provided historical accounts of women's activities or experiences but did not detail specific ways for teachers to present this information. Other articles were eliminated because their discussion of attending to women in social studies were presented as "suggestions" rather than specific descriptions of class activities that could be categorized and analyzed as lesson plans. Further, articles describing approaches that attended to women's history and women's issues in teacher education or higher education in general were also excluded. Finally, two articles in the search, written by the same author, described the same lesson plan; I chose to analyze the version written in a manner that would enable teachers to most easily replicate activities and materials. After this round of analysis, I identified 16 articles that met the criteria of including substantial instructions for learning experiences and having a focus on women. These articles compose the dataset I used for the study presented in this article.

I conducted a two-stage analysis of each of the 16 lesson plan articles. First, I analyzed the rationales presented in the lesson plans - the argument typically embedded in the first several paragraphs of the lesson justifying why the lesson should be implemented. In the second stage, I compiled all of the texts into one digital document to search for the presence of words that could mark feminist discourse and then considered the contexts in which those words appeared. ${ }^{4}$ 


\section{Rationales for Teaching about Women}

In the first stage of the study, I scoured the lesson plans for language that conveyed an explanation of why doing the lesson was worthwhile. I identified any part of the text related to a rationale for implementing the activity described in the article and noted what the authors drew upon or made reference to justify the lesson. I then read each of the rationales again to identify their commonalities, grouped them by themes, and then grouped them by broader categories by which they could be characterized. To do this, it was necessary to distinguish between what could be identified as the primary purpose of the lesson, as identified by the amount of text used to describe it as well as its placement at the beginning of the article, and secondary justifications, which were typically shorter and located in the description of the lesson itself or in the final paragraphs of the article. The results presented in Table 2 reflect the number of articles in each of the categories outlining the primary purpose of the lesson.

\begin{tabular}{lc}
\hline Table 2. Lesson Plan Rationales & \\
\hline Purpose of the Lesson & Total \\
\hline Technical focus & 8 \\
Offsetting deficit of attention to women in curriculum & 5 \\
Working toward gender equity & 1 \\
No rationale & 2 \\
\hline
\end{tabular}

\section{Emphasizing Technical Skills Instead of Topics}

In half of the lesson plans, technical rationales were presented as the primary reason teachers should enact the proposed lesson. This rationale emphasized the way the lesson would help students build skills deemed important in social studies. For example, in one article, the purpose of the lesson was described as providing students with the opportunity to work with primary documents. All of the primary documents presented in the lesson were written by women and focused on women's lives, and the purpose of using primary documents that foreground women's experiences was couched in terms of providing "a multiple-perspective view of history by incorporating more women's social history" (Kohlmeier, 2004, p. 470). However, this was the only explicit acknowledgment that the lesson focused on women's history. The relationship between the described activities, the gender of the authors of the documents, and the value or challenges of engaging students in curriculum that focused on women's lives and experiences was not addressed further. Instead, the emphasis of the lesson was, as indicated in the rationale stated in the introduction, analyzing and evaluating evidence in primary documents from the perspective of a historian. The learning tasks described would likely have resulted in meaningful discussions and consideration about women's lives, but the purpose of the lesson was described clearly in terms of strengthening students' historical thinking skills.

The centering of skills over content was also evident in an article titled "Unveiling the Hijab" (Langdorf \& Pagan, 2005). In this article, the word "women" was used only once in the first 1,500 words. The rationale presented for the proposed activities was the enactment 
of constructivist learning theories and pedagogical content knowledge in the facilitation of a history learning experience focused on the following question: "What is the meaning of the hijab?" (p. 172). The description of the lesson did include references to the teacher's use of multiple documents regarding Islamic women's lives and noted students' observations that "women are treated as property" (p. 173) and that the hijab was a "symbol of sexism" (p. 175), but how teachers should or could translate a discussion about the hijab to a discussion about sexism in general, or more specifically gender roles within Islam, in Iran or France (the countries within which the consideration of wearing the hijab was discussed) or the United States was not described. Although the hijab is a topic loaded with potential for a meaningful discussion of gender roles and women's oppression and resistance, both by choosing to wear and not wear in particular contexts (cf., Ruby, 2006), this lesson did not explicitly describe the activity as a way to engage students in the consideration of gender systems or inequality. This was evidenced by the fact that the issues regarding women and gender that surfaced during the students' discussion were not acknowledged in the conclusion; the focus instead was on students' intrinsic motivation and the use of primary documents to engage students' problem-solving skills to promote learning. This rationaleas with each of the lesson plans in this technical category-positioned the attention to women within the lesson as neutral content through which to work on the real point of the lesson, which was the development of specific social studies skills.

Another example of the technical rationale was represented in a lesson plan focused on American women's suffrage. Although the social studies skill to be developed in this lesson, civic responsibility, was more abstract than the previous examples, the rationale presented for teaching this lesson was representative of the ways in which the articles in this category neatly separate the purpose of the lesson from the topic under study. The rationale for the lesson was described as follows: "Studying the history of suffrage fosters an appreciation for the right and responsibility to vote, and the power of that civic act. Moreover, it helps students develop a more complete understanding of the dedication necessary to achieve social and political change" (Carter, 2011, p. M4). This purpose supplants the potential rationale of a lesson on suffrage for developing students' understanding of women's perseverance in achieving suffrage for themselves and why this social and political change was necessary for women. A lesson on women's suffrage could be enacted for the purpose of considering women's agency in the face of patriarchal oppression and to explore the ways in which gender injustice was constitutionally embedded and altered, but the rationale provided clearly separates gender inequity from the purpose of this lesson.

\section{Working Toward a More Gender-Balanced Curriculum}

The five articles categorized as offsetting the deficit of attention to women in the curriculum differ from the technically focused lessons in that they promote the lessons as opportunities to include women in the curriculum, and in doing so, work against the thin attention paid to women as a topic in social studies. Each lesson presented specific arguments regarding why lessons about women should be taught in social studies by pointing to one of two areas in which women's absence from the curriculum was notable. The first was the difference between attention to women in curriculum at the university level and 
$\mathrm{P}-12$ social studies, as argued in the lead-off sentence in one article that stated, "Teaching women's history is still emphasized more at the postsecondary level than it is at the elementary and secondary levels despite the exponential growth of scholarship in this area over the last three decades" (Sincero \& Woyshner, 2003, p. 218). The second area was the documented absence of women from textbooks. This critique of textbooks as the rationale for why teachers must work actively to include women was particularly evident throughout one of the articles in this category, in which the authors noted that "History textbooks ... largely portray women as passive bystanders in the world's events with fewer than 11 percent of textbook images and references devoted to specific women" (Hickey \& Kolterman, 2006, p. 190).

While the rationales in these lessons acknowledged the historic marginalization of women in curriculum, they stopped short of addressing why women might be included in the curriculum for reasons that could exceed simple parity. In other words, the rationale was not used to make the case that including women in the curriculum might open up spaces for the consideration of gender equity or to examine structures and processes that have systematically marginalized women. These lessons did acknowledge that they were specifically about women and that including women in the curriculum was important, but this rationale failed to harness more critical arguments regarding why women should be included in social studies and what larger purposes it may serve.

\section{Promoting Gender Equity}

In contrast, the rationale presented in the one lesson categorized as working toward gender equity clearly identified social studies as a space where gender equity should be addressed. This geography lesson plan began with the following question: "How often do [teachers] identify gender inequity as a world problem, worthy of attention in social studies classes?" (Richburg, Nelson, \& Tochterman, 2002, p. 23). The purpose of this lesson was described as a way to respond to the lack of attention to these topics to "create awareness of the gender and development inequities women face in the world today" through an inquiryand problem-based activity (p. 23). Thus, the gender equity focus of the lesson was presented explicitly as the rationale, positioned as more important than both the development of a particular skill or balancing the attention paid to women in the curriculum. Also foregrounded in the introduction were the statements that women earn less than $10 \%$ of the world's income, hold only $1 \%$ of chief executive positions in the world, and represent $70 \%$ of the world's poor. Further, the warrant for teaching the lesson included the following quote from an Amnesty International report: "Every year, a vast number of women and young girls are mutilated, battered to death, burned alive, raped, trafficked for domestic or sexual purposes primarily because they are female (Women's Rights Project 1995, p. 23)." This is an explicitly critical rationale for why teachers should engage in these topics. There's no skirting around the issue in this introduction. Through their use of statistics highlighting gender inequality, the authors generate a gender-equity-focused reason for doing this lesson and point to the lesson's potential to engage students in the consideration of gender issues. 


\section{No Rationale Required?}

The two articles presenting no rationale for teaching the lessons they described may appear to be inert in terms of their specific contribution to the conversation about why attending to women in social studies is necessary. However, building on Grant and Wieczorek's (2000, p. 924) assertion that "[a]bsences and presences are not produced in a vacuum, but connect to social, cultural and historical currents that can be traced and analyzed to see how they affect present practices," the argument can be made that what is absent is still relevant. For example, it may be possible to argue that the lack of any warrant for these lesson plans reflects an environment in which most teachers would just want to do this kind of work, and therefore, no convincing is necessary. However, in light of the overwhelming evidence that women continue to be excluded as topics in social studies, I contend that the absence of rationales for implementing these lessons both reflects and contributes to some ongoing problems in social studies. One is the potential to acquit social studies teachers from seeing the need to adopt these lessons if attention to women does not reflect their interests or their knowledge base. In other words, the absence of a convincing argument for why this work should be done, and specifically why social studies teachers are responsible for including these topics, may contribute to the impression that there is an option to choose to attend to women or not on the basis of preference.

This is particularly concerning in relation to the two lessons without rationales, which both (a) provided descriptions of women and historical or political events with whom most social studies teachers are likely to be unfamiliar and (b) tasked students with considering aspects of gender inequity that are not regularly addressed in social studies. For example, one article traced Belva Lockwood's struggle to become the first woman admitted to the Bar of the U.S. Supreme Court. In addition to providing an account of Lockwood's experiences for students to read, the suggested activities included encouraging students to identify five significant milestones achieved by women before and after the passage of the Nineteenth Amendment and to discuss the restrictions placed on people on the basis of gender (Potter, 2002). The lesson has the potential to be used in U.S. history or civics courses. The reading and proposed student activities could generate engaging and important conversations about the way gender shapes women's life options, now and in the past. But by not explicitly addressing why teachers should adopt this lesson and describing what engaging in this lesson might achieve, this article is silent on what should compel the teacher - who is likely to be learning about Lockwood for the first time and, further, who may not be personally invested in including women in the curriculum - to incorporate working this potentially gender-equity-focused lesson into their plans. My goal is not to imply that lessons like these lack value but to question whether warrantless lessons about women can possibly meet the challenge that lies within any attempt to encourage social studies educators to enact these kinds of activities and to consider why thinking about women, women's lives, and gender equity are worthwhile activities in social studies classes.

While the two articles without rationales clearly fell short of naming the social studies curriculum as a place to explore power relations and gender inequality, the dataset as a whole reflected a normative commitment to justify attending to women in the classroom in ways that deemphasize critique. With the exception of the geography lesson focused specifically on gender injustice, the other plans in the dataset did not call upon discourses 
of gender equity as justifications. Rather, the rationales deployed presented a rather narrow set of options for why women should be included, relying on softer and easier-toswallow warrants, such as inclusion or focusing on social studies skills through lessons that just happen to include women. In the next section, I draw on Tomlinson's (2010) analysis of civil affect in academic writing to theorize the uncritical tone normalized in the lesson plans and to make the argument that the tone of women-focused work can change.

\section{Civility and Its Consequences}

Feminist Barbara Tomlinson's (2010) work on rhetoric, affect, and feminist tropes is particularly helpful for unpacking the norms that have shaped the rationales for teaching about women present in these lesson plans. In her discussion of the ways in which the affect of a text works to create its authority in academic writing, Tomlinson argued that in academic texts, a tone of civility and politeness is normalized as appropriate, stating, "Texts are evaluated as if they were stand-ins for restrained, face-to-face conversations conducted according to the norms of white middle-class social interactions. In such a view, 'Raised voices,' blunt terms, and confrontive claims violate standards of textual manners" (p. 60). There are specific parameters that constrain the tone that an argument to include women can take, as standards of civility are dictated by much broader discourses than just those found within academia or in social studies. How attention might be drawn to gender inequality is a tricky discursive business, because, Tomlinson noted, "for some readers, simply being put on notice that unpleasant social problems remain an ongoing feature of many people's lives may appear dismaying, disagreeable, divisive" (p. 60). The impetus to adopt a civil tone in one's advocating for attention to women, to avoid the appearance of impoliteness or confrontation, then, is one possible explanation for why these lesson plan rationales were written in the ways I described. Lesson plans that described the rationale for attending to these topics through polite references to getting women included, as well as those lesson plans not acknowledging gender at all in the rationale, might reflect an impulse to promote gender work politely.

The problem with this adherence to civility, Tomlinson (2010) argued, in the practice of attending to political issues is that it exchanges etiquette for ethics: choosing to err on the side of politeness foregrounds the affect of a text over the substantive critique upon which the argument is being made. Tomlinson contended, "Rather than being 'impartial', such conventions serve entrenched interests by encouraging aggrieved parties to give up part of their bargaining power-their emotional force and its consequences - prior to negotiation" (p. 60). The sacrifice of emotion for the appearance of politeness insulates both the author and the reader from their shared accountability for an inequitable society, failing to harness the power of textual arguments to compel us to think about ourselves and our lives in relation to others.

The polite rationales for addressing women in the lesson plans, I argue, make it possible for teachers to ignore the topic, or to not engage with it in critical ways, because it falls short of implicating the reader/teacher (and all of us) in the maintenance of gender inequity. In terms of social studies education in particular, Levstik has noted that "this tendency to omit or oversimplify in order to be polite seriously misrepresents complex issues, 
including the struggles for women's rights" (Levstik, 1997/1998, p. 26), and that by substituting a "cult of politeness" for social critique, "the social studies classroom emphasizes the obvious, cheerful, and stereotypical and obscures the ways in which structures of class, race, and national power, as well as gender, constrain groups and individuals" (Levstik, 2001, pp. 196-197). Disrupting the gender status quo through social studies curriculum in ways that students will notice, she argued, requires an account of gender in ways that "are more than benevolently inclusive" (Levstik, 1997/1998, p. 27).

When authors continue producing work advocating for attention to women and gender, or any other marginalized group, in civil and polite ways, the tradition of civility persists. This, in turn, has consequences for researchers and gender-equity advocates who, in an effort to achieve textual vehemence, adopt a more critical affect in their writing. Continued adherence to textual norms of politeness

[A] uthorizes readers to treat writers [who are] perceived as angry as if they were obstreperous children, to ignore their arguments, to resist their emotional and moral force, to evade confrontation ... in effect, to say, "You need to calm down before I listen to you." (Tomlinson, 2010, p. 60)

In other words, the persistent reinscription of the civil affect in academic writing ensures that a critical tone remains outside the set of choices available to those who have something to say about gender and inequity and also wish to have their work published and read. In this sense, adhering to norms of civil academic discourse has effects far beyond those experienced directly by a single author - it sustains a tradition that makes it difficult for those attempting to deploy other affective techniques to be heard.

My purpose is not to dissuade teachers from teaching women-focused lessons that do not include an explicit critique but instead, following Segall (2004, p. 161), to ask "what is absent in that which is present in the discourse of social studies?" The overwhelming absence of critical discourses to justify why attending to women in the curriculum is necessary or how it can be used to engage students in the consideration of inequity may demonstrate that a particularly noncritical way of thinking about why women should be included has been normalized, at least in terms of how authors are imagining attending to women as topics in the classroom and the ways we are framing these topics for practitioners. From a feminist perspective, the purpose of promoting attention to women in curriculum is not simply to make sure women are included but to drag gender issues, experiences, and beliefs into our broader social studies conversations about life in the present and the past. However, when combined with such scant teaching of women in social studies in general, these lessons reflect a normalized approach to including women that is unlikely to integrate a critical consideration of gender in any substantial way.

\section{Critical Feminist Language}

To further investigate the discourses about women and gender equity that are available to and acceptable within the social studies community, I combined digital versions of all of the lesson plan texts into one file and then searched for words that appeared frequently in 
critical and feminist literature with warrants for the promotion of gender equality. These words, which appear in Table 3, were chosen because they often signify feminist discourses and/or signal political and rhetorical attention to women and women's issues in Western literature and research.

\begin{tabular}{lcccc}
\hline Table 3. Occurrence of Feminist Markers & & & \\
\hline Term & $\begin{array}{c}\text { Total } \\
\text { occurrences }\end{array}$ & $\begin{array}{c}\text { Number of } \\
\text { articles }\end{array}$ & $\begin{array}{c}\text { Related to } \\
\text { rationale }\end{array}$ & $\begin{array}{c}\text { Appeared in } \\
\text { reference }\end{array}$ \\
\hline Women's rights & 16 & 6 & 0 & 2 \\
Equal rights & 5 & 4 & 0 & 0 \\
Gender bias & 0 & 0 & 0 & 0 \\
Feminist & 2 & 2 & 0 & 2 \\
Feminism & 0 & 0 & 0 & 0 \\
Patriarchy & 0 & 0 & 0 & 0 \\
Sexism & 0 & 0 & 0 & 0 \\
\hline
\end{tabular}

Of the discourse markers searched, the terms "women's rights" and "equal rights" appeared across the widest number of articles. In light of the analysis of the rationales, it is not surprising that none of these appearances were related to the warrants for teaching the lessons. A closer look at the references to "equal rights," however, is worthwhile, particularly within an analysis of the presence of political feminist language in the discourse of social studies. For example, only one of the occurrences of this phrase marks a reference to the Equal Rights Amendment. It appears in an activity for elementary students, titled "Honoring Special Women" (Hickey \& Kolterman, 2006). The article includes images of 10 stamps depicting famous U.S. women, listing the date the stamp was issued and a short phrase describing each woman's "contribution." Students are to be divided into groups to review the stamps and then tasked with creating stamps to represent special women in their own lives. One of the famous women depicted is Alice Paul-her contribution is described as "Founder of National Women's Party and author of Equal Rights Amendment" (Hickey \& Kolterman, 2006, p. 193). Another occurrence of "equal rights" appeared in the previously described lesson on Belva Lockwood, which noted that she was the Equal Rights Party candidate for president in 1884 and 1888. The other three appearances of "equal rights" reference the political rights of women in places outside the United States. Similarly, all of the references to "women's rights" are made either to historical periods in the United States prior to the passage of the Nineteenth Amendment or reference women living outside of the United States. These are very narrow glimpses of attention to women's political efforts. Even among a small sample of lessons, it is possible to identify a pattern of attention to women's equality and rights in which the topic appears to be relevant only to activities occurring in the presuffrage past or to women in places other than the United States.

As Table 3 indicates, there are no references to gender bias, feminism, patriarchy, or sexism in these articles. The word "feminist" appears twice but only in references. In one instance, it is within the title of a book about Alice Paul, and in the other, it is embedded within a citation of a publication produced by the Feminist Press publishing house. The definition of each of the words or phrases in the search is contested, and therefore, the 
presence of these terms would not be a definitive marker of what a text "is about." However, the absence of these terms from the lesson plans is conspicuous. Although there may be a range of ways to work against gender inequity without using the words "feminism" or "sexism," for example, the use of these words, as well as the feminist label, and the invitation to a critical stance they offer, does matter. Their absence points to the work of politics, power, and identification and leads us to question the connection between the absence of these terms and the lack of attention in the lesson plans to systemic political, economic, and cultural structures and potentially uncomfortable explorations of women's status in society. These concerns, which reflect feminist arguments for including women in curriculum, would seem to be salient in lesson plans that promote attention to women in a field that has largely ignored these topics. Yet these ideas are not present in the texts.

There could be a variety of explanations for this absence. Among the scholars contributing to the body of literature documenting women's absence from the social studies curriculum, Margaret Crocco, in particular, has focused on understanding why and how women have been excluded. The explanations she has discussed include high-stakes testing and the contraction of the standards (2006a, 2007; Crocco \& Cramer, 2005), attention to race and culture over gender (Crocco, 2008), and a focus on political history over social history (Crocco, 2008). While these structural issues have certainly contributed to traditional, status quo social studies, Crocco has also pointed to more subtle factors inhibiting attention to women, including the overall conservatism of the field $(2007,2008)$ and "lingering patriarchal, sexist attitudes" (Crocco, 2006b, p. 181). In the analysis that follows, I turn to related discursive constraints that make it difficult for critical attention to gender inequity and feminism to flourish in our field.

The re-emergence of attention to gender at this moment compels us to consider how the discursive tools provided by feminism - to resist normative constructions of gender and to investigate gender as a category of analysis in the deconstruction of power imbalances - could be made available to students and teachers as they explore and seek to understand history, civics, economics, and geography and the world in which we now live. It is not enough, however, to just assert that there should be more feminism in the field or to argue that drawing on feminism could enrich lessons with a more critical perspective on gender in social studies. Instead, it seems necessary to understand what has been keeping feminism out of the field in the first place. As Davies (2003, p. xiii) argued, if poststructural theory compels us to see the world as the product of powerful discursive practices, the investigation of those discourses makes it possible "to see how we can change that world through a refusal of certain discourses and the generation of new ones." In the following section, I turn to feminist theory to understand some discursive forces that may be constraining the possibility of taking up a feminist subject position in educational research broadly, and in social studies specifically, to argue that the negative stigmatization of feminism and perceptions of irrelevance are two obstacles to the adoption of a feminist stance in our field. 


\section{The Untenability of Feminism in Social Studies}

The polite tone of the rationales and the general avoidance of politicized language in the lessons, even when the topics, such as suffrage, are clearly related to issues of feminism, patriarchy, and gender inequity, may reflect an aversion to the possibility that the lessons will be categorized as feminist - or that the author will be labeled a feminist. The problematic perception of feminists has already been noted in social studies research. For example, the eighth-grade participants in one study (Levstik \& Groth, 2002) described feminists as "women who think men aren't equal ... the ones who shave their heads, they hate men so much" (p. 244) and who see men as "pigs." The students articulated that "[b]eing labeled feminist meant risking being labeled lesbian" (p. 248) and that the term "feminist" was a weapon that the students felt could, and had been used against other students (p. 248). According to Levstik and Groth (2002), "students uniformly agreed that the term 'feminist' was a problematic and often uncomfortable label. 'It can be an insult,' [one of the participants] explained. 'It means you hate men,' at least one student in all but one group said" (p. 249). They noted that the perception of being antimale was "a dangerous stance among adolescent girls who spent so much energy on attracting male attention" (p. 245).

These beliefs about feminism and feminists are also found in social studies research that focused on teachers. In her discussion of a study with preservice and in-service teachers, Levstik described a conversation about suffrage in which "some adults strongly identified with women in the women's movement, others were just as adamant in not doing so" (Levstik, 2000, p. 289). She noted, in particular, that some of the younger women distanced themselves from those they perceived as "women's libbers." One of the most vocal of this group explained, "I'm just not a big women's lib type of person . . . and . . there's so many more like me." Across discussion groups, opinions varied from complete agreement on the importance of women in history to ambivalence and, occasionally, outright hostility (Levstik, 2001, p. 197).

Much like the eighth-grade students in Levstik and Groth's (2002) study, social studies preservice teachers in a study conducted by Monaghan (2014) described feminists as being perceived as people who "hate men," who see "men as the cause of all of your problems," and who are "crazy" (p.9). She found that the participants in her study perceived feminists as "annoying, polarizing, radical, lesbian, man-haters" (p. 9) and concluded that it was easy to see why even those people in her study who identified with feminist goals went to lengths to avoid self-identifying or being labeled as a feminist.

Tomlinson (2010, p. 1) asserted that "one never encounters the feminist's argument for the first time because it comes already discredited." The feminist tropes that seemed to be so readily available and intelligible to both eighth-graders and preservice teachers in these studies, and the similarities in the language they used to describe feminists, are a confirmation of the antifeminist discourses circulating in our culture. These tropes rely upon several pervasive assumptions about feminism - first, that feminism is inherently an antimale, radical, and illogical stance; and second, that feminism is equated with lesbianism, made more rhetorically forceful - and incredibly troubling - because lesbians are interpellated as abject subjects. It is important to note, however, that the negative stigma around feminism is not just a simple misunderstanding or lack of knowledge, but that it 
undermines the take up of feminism as a productive force for social change. In other words, this way of talking about feminists works toward what Quinn and Radtke (2006) labeled the untenability of feminist identity, regulated in part thorough the production of feminists as radical, lesbian extremists "as a means of resisting feminism and producing minimized feminist subject positions" (p. 196).

Antifeminist rhetoric has significant consequences for those who might consider taking up a feminist subject position to rationalize their work. As Eckert and McConnell-Ginet (1992) argued,

Even those who recognize that many (perhaps even most) feminists are quite different from the sometimes monstrous creatures of the stereotype may (with some justification) fear that others not so enlightened will take the feminist label at its most negative. (p. 230)

While discourses about feminism emanate from outside of education and social studies, they have contributed to shaping what can and cannot be said in social studies lesson plans that include women. When considering why feminism has not been taken up in the lessons described in this study and beyond, it is then important to not "disembed the individual from the social" (Dillabough, McLeod, \& Mills, 2008, p. 307) by positioning authors as actors who are free from the discourses that inhibit the adoption of a feminist and antisexist stance. As Weedon (1987) explained,

The individual is both the site for a range of possible forms of subjectivity and, at any particular moment of thought or speech, a subject, subject to the regime of meaning of a particular discourse and enabled to act accordingly. (p. 34)

The feminist subject position - and the critical orientation toward the promotion of gender equity in social studies classrooms that can come along with it - may not be a readily available subjectivity in our field. A status quo change is needed to open the space for critical feminist explorations of gender structures and inequities in social studies classrooms. Addressing and unpacking these problematic perceptions of what feminism is and creating opportunities for students and teachers to learn about and from feminisms and feminists are important issues for our field to address.

\section{The Irrelevance of Feminism in Social Studies (and Beyond)}

The positioning of feminism as an outdated relic of the past and a theoretical tradition with little to offer today poses another challenge to its integration into social studies. The belief that gender equity issues are something that we have moved past and that sexism and patriarchy no longer impact structures or interactions is a significant obstacle to the adoption of a feminist stance in educational research. There are multiple discourses that impact the perception that feminism is an artifact of previous generations, but in this section, I explore the possibility that these attitudes have been impacted by neoliberal discourses. 
Harvey (2007) described neoliberalism as a political-economic force that promotes practices and interactions based on the understanding that human well-being can best be achieved by securing and protecting individual freedoms. The consequence of the veneration and promotion of individual freedom is that, "each individual is held responsible and accountable for his or her actions and well-being. ... Individual success or failure are [sic] interpreted in terms of entrepreneurial virtues or personal failings . . . rather than being attributed to any systemic property" (pp. 65-66). Neoliberalism is a dominant discourse in our times, having an impact on not only our political and economic behavior but many other aspects of our way of living in the world, including our perceptions of gender equity and inequity.

For example, through its valorization of individual freedom, neoliberalism may constrain the adoption of a feminist subject position that supports political action on behalf of women as a collective group. As Baker (2005) argued, the relationship between neoliberal ideas of meritocracy and personal responsibility for success and feminists' arguments for gender equity are incongruent. The perception that women enjoy more "choices" and "freedoms" than women in previous generations, which are rights central to neoliberal thought, can cloak structural inequality and lead to the perception that gaps between women and men in terms of representation in Fortune 500 companies (Guerrera, 2013), for example, are the result of the different choices women and men have made. The pervasive influence of neoliberalism on our daily lives individualizes success, as well as disadvantage and adversity, in ways that mask the influence of any forces beyond our own agency and our own choices. Feminism, although diverse and dispersed, is a political and theoretical project that recognizes that there are practices and processes that contribute to the systemic oppression of women everywhere. But the need for these politics can appear superfluous in a world in which individuals are perceived to be at the reins of their own destiny. Additionally, feminism, because of its focus on women's unequal status, can be perceived to connect women to oppression (and deficiency or weakness) for reasons that lie outside their control. In a study of young women's rejection of the feminist subject position, Rich (2005) noted that for the participants in her study:

To engage in a feminist discourse was to be associated with disadvantage, or to draw upon a position of "victim" or to be the "pathetic female." To draw on a traditional feminist discourse was for these young women, to risk including disadvantage in their narratives, to be the victim of male oppression, and rupture a powerful sense of self-determination so intimately bound with the discourse of individualization. (p. 504)

Rich (2005) contended that these women "tended to assume a separation of self from gendered contexts, and a belief that one's individual determination to become or achieve something . . . is enough to overcome social constraint" (p. 501). In this way, neoliberal thought, which constructs people as free and rational agents limited only by their own imagination and determination, inhibits the recognition of structural obstacles that prevent women from participating equally in many sectors of social, economic, and political life. 
To embrace feminism and to occupy the feminist subject position requires the acknowledgment that there are forces at work beyond those we can direct individually. The impetus to resist being positioned as a feminist, therefore, may also occur because of the impetus to see ourselves (and others) as agents who are entirely free to shape their own lives. It is understandably empowering to see oneself as limited only by hard work and imagination, and there is a great lure to accept this belief as a common-sense assumption (Rose, 1999) and to infuse this way of thinking about the world into the social studies curriculum, even when presenting historical or current events that deal directly with marginalized and oppressed groups of people. ${ }^{5}$ Kumashiro (2001) argued about the danger of this kind of common sense in his assertion that,

Perhaps we desire teaching and learning in ways that affirm and confirm our sense that what we have come to believe is normal or commonsense in society is really the way things are and are supposed to be ... perhaps we resist anti-oppressive practices because they trouble how we think and feel about not only the Other, but also ourselves. (p. 5)

While the notion to believe that gender inequity is a thing of the past is seductive, resistance to recognizing structural explanations for gender imbalances impedes critical feminist projects that promote attention to gender and women in our culture. To move toward curriculum and lessons that address gender inequity explicitly, it is important to consider and understand the ways in which neoliberalism has constructed common-sense norms of individual agency that create obstacles to attending to women and gender in social studies in a critical and collective way.

\section{Conclusion}

How can we transform our curricula at all levels of the formal educational system using feminist scholarship and knowledge in climates that are hostile? (Bernard-Powers, 1996, p. 2).

In a discussion of the place of critical theory in social studies, Crocco (2006c) concluded that, "I now suspect that the low profile of theory within social studies may have been a contributing factor explaining feminism's difficulties" (p. 232). The importance of critical theories, she noted, is that they "provide frameworks for critiquing the world-past and present-and tools for dismantling the status quo in order to build alternative ways of seeing, being, and acting" (p. 233). Crocco posited that these kinds of tools are necessary for dismantling the status quo of ignoring women in social studies. The data presented in this paper confirm Crocco's assertion about the lack of traction feminism has gained in the field. My goal in paying close attention to these lessons was not to point a finger at their authors but rather to shed light on some of the discursive constraints that inhibit the take up of feminism for all of us - students, teachers, and scholars - in social studies education. In doing so, I hope to spark some dialogue about revamping feminism's image and creating opportunities for members of the social studies community to be exposed to feminists, 
feminist theories, and accurate information about the theoretical tradition. In doing so, I echo Segall's (2013) call for "a revitalization of critical discourses in our scholarly work in social education" (p. 488).

The overwhelming presence of a civil affect and the absence of critical feminist work in social studies $\mathrm{P}-12$ spaces is not only a missed opportunity but contributes to status quo social studies that does little to acknowledge or counter social inequity. Without the pervasive use of these kinds of theories or a tone in our work that underscores the urgency of the changes that need to be made, scholars have struggled to make significant changes in the kinds of traditional social studies teaching and research we produce and promote (Ladson-Billings, 2003). For social studies to be a space in which gender equity can be taken seriously, more critical approaches to including women in social studies are needed to emphasize that the relationship between historical or contemporary political, social, and economic conditions for women is rooted in systems of power. As has been argued throughout this article, feminism is a particularly powerful tool for prying open these spaces in our curriculum and sparking important conversations.

Focusing on discourse rather than structure or policy to make this argument is important because it draws attention to some of the ways in which unspoken and unacknowledged aversions to such critical theories as feminism impact our work as scholars. A discursive focus also lends itself to arguing that the regulation of attention to women and gender in social studies (or any other equity topic) does not require guards posted at the entrance of College and University Faculty Assembly (CUFA) ${ }^{6}$ conferences with "No feminists allowed" signs. The ways in which the feminist subject position has been excluded within the social studies research community are much more subtle. To be sure, the disciplining of the discipline is achieved in part through the exclusion of these topics by state school boards or textbook designers, but it is also achieved in microevents within the scholarly community, as seen, for example, in the exclusion of critical warrants for implementing lesson plans about women. Although the interactions of power and knowledge in these small spaces may be difficult to recognize, this is certainly one of the ways the gatekeeping happens. It is critical to push against these constraints by putting them out there in the light of day and asking others to consider the ways in which these seemingly small decisions contribute to the equity void in the field.

In our work with and for practitioners, avoiding feminism and a feminist stance in work that promotes the inclusion of women in the curriculum has consequences. Ignoring opportunities to rely upon feminism and other critical theories as the basis for the promotion of social studies pedagogy and practice has consequences. Overcoming the aversion and resistance to feminism that circulates in our culture is not something that can be achieved by individuals acting alone but by pointing out what has been excluded and examining some of the broader discourses that are governing that exclusion, I seek to open up the space for authors and researchers to become more aware of their agency to reject the limitations imposed by antifeminist rhetoric. In other words, I hope that we might practice "the art of not being governed so much" (Foucault, 2007, p. 45) and access more critical discursive technologies, such as feminism, available to us as researchers and teachers to disrupt the power that sustains status quo social studies, both in terms of the continued 
marginalization of women and feminism and the norms around how we talk and write about these topics.

Acknowledgments - The author wishes to thank Meg Monaghan and Hilary Hughes for their feedback.

\section{Notes}

1. The use of "feminism(s)" is an acknowledgment that feminism is a term that does not signify a monolithic or static theoretical field. There are many different kinds of feminisms and feminists. In the rest of this article, I use the word feminism to refer to a broad range of theories that foreground gender inequity as a primary concern.

2. At the time the search was conducted, ERIC did not contain information about articles in Social Education from 2002 or 2003, Social Studies and the Young Learner from 2001 to 2003, and any record of Middle Level Learner. I looked at each of those issues individually to identify any articles pertinent to the search.

3. To construct the gender list, I used the ERIC Thesaurus function to identify any descriptors related to gender. The search included descriptors like "gender bias," "feminism," and "sex role." To develop a list of ERIC descriptors related to instruction that was likely to capture lesson plan oriented pieces, I looked at the lesson plan-type articles published in Social Education in 2008 and collected every instruction-related descriptor assigned to those articles in ERIC. The instruction search included terms like "learning activities," "simulation," and "primary sources."

4. The need to examine the intersectionality of gender with other subjectivities, for example, race, class, and sexuality, is a critical component of feminism, as noted in the introduction. In this study, I chose to pay close attention to gender, specifically, women. While this allowed for a deep analysis of how women were addressed in the data, it did not allow for an equally thorough analysis of the intersecting attention to other subjectivities. This is a significant limitation on several levels: first, because women's experiences are inextricably intertwined with other subjectivities that have material effects on their lives, and second, because many of these lesson plans described women in contexts in which the intersection of their subjectivities was essentially the topic under study. However, this particular study focused primarily on the rationales used to teach these lessons. In my analysis, I found that when a rationale was presented, the subjectivity most likely to be emphasized was gender, even when race, class, religion, or place were equally if not more germane subjectivities to consider in relation to the topic/content presented. This is due, at least in part, to the ways in which the data were selected, but likely has more complex and troubling explanations. Considering the ongoing critiques of the lack of attention to race and sexualities in social studies, for example, these issues are ripe for analysis but beyond the scope of this study.

5. This extends to the propensity to focus on individuals who resisted oppression over attention to collective action of groups, evident, for example, in the separation of Rosa Parks from the local NAACP chapter of which she was a part (Kohl, 2007).

6. CUFA is an affiliate group of the NCSS. 


\section{References}

Alpern, M. (1978). Images of women in European history. Social Education, 42, 220-227.

Bajaj, V. (2013, October 12). The striking absence of women. The New York Times, SR10.

Baker, J. (2005). The politics of choice: Difficult freedoms for young women in later modernity (Unpublished doctoral dissertation). Cardiff University, Cardiff, Wales, England.

Bernard-Powers, J. (1996). Engendering social studies: Perspectives, texts, and teaching. Theory \& Research in Social Education, 24(1), 2-7. doi:10.1080/00933104.1996.10505766

Carter, C. (2011). Raise up your cloth! The woman suffrage movement's second generation. Middle Level Learning, 40, M2-M7.

Crocco, M. S. (2004). Women and the social studies: The long rise and rapid fall of feminist activity in the National Council of the Social Studies. In C. Woyshner, J. Watras, \& M. S. Crocco (Eds.), Social education in the 20th century (pp. 142-159). New York, NY: Peter Lang.

Crocco, M. S. (2006a). Caught between invisibility and stereotyping: Teaching the novel "Shabanu." Social Education, 70, 178-182.

Crocco, M. S. (2006b). Gender and social education: What's the problem? In E. W. Ross (Ed.), The social studies curriculum: Purposes and possibilities (3rd ed., pp. 171-193). Albany: SUNY Press.

Crocco, M. S. (2006c). The invisible hand of theory in social studies education. In A. Segall, E. Heilman, \& C. Cherryholmes (Eds.), Social studies: The next generation (pp. 231-236). New York, NY: Peter Lang.

Crocco, M. S. (2007). Speaking truth to power: Women's rights as human rights. The Social Studies, 98, 257-269. doi:10.3200/TSSS.98.6.257-269

Crocco, M. S. (2008). Gender and sexuality in the social studies. In L. S. Levstik \& C. A. Tyson (Eds.), Handbook of research in social studies education (pp. 172-196). New York, NY: Routledge.

Crocco, M. S., \& Cramer, J. (2005). Women, webquests, and controversial issues in the social studies. Social Education, 69, 143-149.

Davies, B. (2003). Frogs and snails and feminist tales: Preschool children and gender. Cresskill, NJ: Hampton.

DeLeon, A. (2010). Introduction. In A. DeLeon \& E. W. Ross (Eds.), Critical theories, radical pedagogies, and social education: New perspectives for social studies education (pp. ix-xvi). Rotterdam, The Netherlands: Sense.

Dillabough, J., McLeod, J., \& Mills, M. (2008). In search of allies and others: 'Troubling' gender and education. Discourse: Studies in the Cultural Politics of Education, 29, 301-310.

Eckert, P., \& McConnell-Ginet, S. (1992). Think practically and look locally: Language and gender as community-based practice. Annual Review of Anthropology, 21, 461-490. doi:10.1146/annurev.an .21.100192.002333

Fairclough, N. (2003). Analysing discourse: Textual analysis for social research. London, England: Routledge.

Foucault, M. (1977). Language, counter-memory, practice, trans. Donald F. Bouchard and Sherry Simon. Ithaca, NY: Cornell University Press.

Foucault, M. (2007). What is critique? In S. Lotringer \& L. Hochroth (Eds.), The politics of truth (2nd ed., pp. 41-82). New York, NY: Semiotext(e).

Grant, C., \& Wieczorek, K. (2000). Teacher education and knowledge in 'the knowledge society': The need for social moorings in our multicultural schools. Teachers College Record, 102, 913-935. doi:10.1111/0161-4681.00084 
Greenhouse, E. (2013, August 1). Twitter's free-speech problem. The New Yorker. Retrieved from http://www.newyorker.com/online/blogs/elements/2013/08/how-free-should-speech-be-ontwitter.html

Guerrera, F. (2013, December 16). Wall Street lags on women's roles. The Wall Street Journal. Retrieved from http://online.wsj.com/news/articles/SB10001424052702304173704579261931042730484

Hahn, C. L. (1975). Eliminating sexism from the schools: An application of planned change. Social Education, 39, 133-136.

Hahn, C. L., Bernard-Powers, J., Crocco, M. S., \& Woyshner, C. (2007). Gender equity in social studies. In S. S. Klein (Ed.), Handbook for achieving gender equity through education (2nd ed., pp. 335357). Mahwah, NJ: Erlbaum.

Hahn, C. L., Bernard-Powers, J., Hunter, L., Groves, S., MacGregor, M., \& Scott, K. (1985). Sex equity in social studies. In S. S. Klein (Ed.), Handbook for achieving sex equity through education (pp. 280297). Baltimore, MD: John Hopkins University.

Harvey, D. (2007). A brief history of neoliberalism (2nd ed.). Oxford, England: Oxford University Press.

Henry, A. (2004). Not my mother's sister: Generational conflict and third wave feminism. Bloomington: Indiana University Press.

Hickey, M., \& Kolterman, D. (2006). Special women in my life: Strategies for writing women into the social studies curriculum. Social Education, 70, 190-196.

Hicks, S., \& Taylor, C. (2008). A complex terrain of words and deeds: Discourse, research, and social change. In P. Cox, T. Geisen, \& R. Green (Eds.), Qualitative research and social change (pp. 52-73). Basingstoke, England: Palgrave Macmillan.

Kohl, H. (2007). She would not be moved: How we tell the story of Rosa Parks and the Montgomery Bus Boycott. New York, NY: New Press.

Kohlmeier, J. (2004). Experiencing world history through the eyes of ordinary women. Social Education, 68, 470-478.

Kumashiro, K. (2001). "Posts" perspectives on anti-oppressive education in social studies, English, Mathematics, and science classrooms. Educational Researcher, 30(3), 3-12. doi:10.3102/0013189X 030003003

Ladson-Billings, G. (2003). Lies my teacher still tells: Developing a critical race perspective toward the social studies. In G. Ladson-Billings (Ed.), Critical race theory perspectives on social studies: The profession, policies, and curriculum (pp. 1-11). Greenwich, CT: Information Age.

Landorf, H., \& Pagan, L. (2005). Unveiling the hijab. The Social Studies, 96, 171-177. doi:10.3200/TSSS .96.4.171-177

Lather, P. (1991). Getting smart: Feminist research and pedagogy within the postmodern. New York, NY: Routledge.

Levstik, L. S. (1997/1998). Early adolescents' understanding of the historical significance of women's rights. International Journal of Social Education, 12(2), 19-34.

Levstik, L. S. (2000). Articulating the silences: Teachers' and adolescents' conceptions of historical significance. In P. Stearns, P. Seixas, \& S. Wineburg (Eds.), Knowing, teaching, \& learning history (pp. 284-305). New York: New York University.

Levstik, L. S. (2001). Daily acts of ordinary courage: Gender-equitable practice in the social studies classroom. In P. O'Reilly, E. M. Penn, \& K. B. DeMarrais (Eds.), Educating young adolescent girls (pp. 189-211). Mahwah, NJ: Erlbaum. 
Levstik, L. S., \& Groth, J. (2002). "Scary thing, being an eighth grader": Exploring gender and sexuality in a middle school U.S. history unit. Theory \& Research in Social Education, 30, 233-254. doi:10 .1080/00933104.2002.10473193

MacLure, M. (2003). Discourse in educational and social research. Buckingham, England: Open University Press.

Maher, F. (1987). Inquiry teaching and feminist pedagogy. Social Education, 51, 186-192.

Mohanty, C., Russo, A., \& Torres, L. (Eds.). (1991). Third world women and the politics of feminism. Bloomington: Indiana University Press.

Monaghan, M. (2014). Gender equity and education: Examining preservice teachers perceptions. Gender, Education, Music, and Society, 7(8), 4-12.

Morago, C., \& Anzaldúa, G. (Eds.). (2002). This bridge called my back. Berkeley, CA: Third Woman.

Potter, L. (2002). A bill to relieve certain legal disabilities of women. Social Education, 66, 117-120.

Quinn, J., \& Radtke, H. L. (2006). Dilemmatic negotiations: The (un)tenability of feminist identity. Psychology of Women Quarterly, 30, 187-198. doi:10.1111/j.1471-6402.2006.00281.x

Rich, E. (2005). Young women, feminist identities, and neoliberalism. Women's Studies International Forum, 28, 495-508. doi:10.1016/j.wsif.2005.09.006

Richburg, R., Nelson, B., \& Tochterman, S. (2002). Gender inequity: A world geography lesson plan. The Social Studies, 93(1), 23-30. doi:10.1080/00377990209599876

Rose, N. (1999). Powers of freedom. New York, NY: Cambridge University Press.

Ruby, T. (2006). Listening to the voices of hijab. Women's Studies International Forum, 29(1), 54-66. doi:10.1016/j.wsif.2005.10.006

Sarkeesian, A. (2012, December 1). Anita Sarkeesian: Sexist online harassment and cyber mobs [video file]. Retrieved from http://tedxtalks.ted.com/video/Anita-Sarkeesian-at-TEDxWomen-2

Schmeichel, M. (2011). Feminism, neoliberalism, and social studies. Theory \& Research in Social Education, 39(1), 6-31. doi:10.1080/00933104.2011.10473445

Schmidt, S. (2012). Am I a woman? The normalisation of woman in US history. Gender and Education, 24, 707-724. doi:10.1080/09540253.2012.674491

Segall, A. (2004). Social studies and the discourses of postmodernity. In C. Woyshner, J. Watras, \& M. S. Crocco (Eds.), Social education in the twentieth century (pp. 160-175). New York, NY: Peter Lang.

Segall, A. (2013). Revitalizing critical discourses in social education: Opportunities for a more complexified (un)knowing. Theory \& Research in Social Education, 41, 476-493. doi:10.1080/00933104 .2013 .836382

Sincero, P., \&Woyshner, C. (2003). Writing women into the curriculum. Social Education, 67, 218-225.

Stone, L. (1996). Feminist political theory: Contributions to a conception of citizenship. Theory $\&$ Research in Social Education, 24(1), 36-53. doi:10.1080/00933104.1996.10505768

Tea, M. (Ed.). (2003). Without a net: The female experience of growing up working class. Emberville, CA: Seal.

Tetreault, M. K. T. (1987). Women, gender, and the social studies. Social Education, 51, 167-168.

Tomlinson, B. (2010). Feminism and affect at the scene of the argument: Beyond the trope of the angry feminist. Philadelphia, PA: Temple University Press.

Trecker, J. (1971). Women in United States History high school textbooks. Social Education, 35, 248-335.

Walker, R. (1992). Becoming the third wave. Ms, 2(4), 39-42.

Weedon, C. (1987). Feminist practice and poststructural theory. Oxford, England: Blackwell. 
Wetherell, M. (2001). Themes in discourse research: The case of Diana. In M. Wetherell, S. Taylor, \& S. J. Yates (Eds.), Discourse theory and practice: A reader (pp. 14-28). Thousand Oaks, CA: Sage.

\section{About the Author}

Mardi Schmeichel is an assistant professor in the Department of Educational Theory and Practice in the College of Education and affiliate faculty in the Institute of Women's Studies at the University of Georgia, Athens, Georgia, USA. She can be contacted at mardi@uga.edu. 